\title{
WEIGHT OPTIMIZATION OF FTAC SECONDARY STRUCTURE OF
}

\section{AN AIRCRAFT}

\author{
Syed KashifHussain ${ }^{1}$, Abdul Nazeer ${ }^{2}$ \\ ${ }^{I}$ Assistant Professor Department of Aeronautical Engineering, Khaja Banda Nawaz College of Engineering, \\ Gulbarga, Karnataka, India \\ ${ }^{2}$ Assistant Professor Department of Mechanical Engineering, Khaja Banda Nawaz College of Engineering, Gulbarga, \\ Karnataka, India
}

\begin{abstract}
The Fuel Tank Access Covers (FTAC) primary function is to provide the aerodynamic surface on the lower wing at the Fuel Tank Access Manholes. These manholes are used in maintenance to access the inside of the wing box. The FTACs also provide sealing of the fuel bays. Fuel Tank Access Cover area include wings, control surfaces, aero engine nacelles, fan casings, etc. These are all safety critical components which may be subjected to high velocity impacts due to bird strike or foreign object damage (FOD). Typically on wing leading edges, nacelles, or on fan blades causing fan blade debris to impact fan casings and wing or fuselage structures. Analysis tools, such as finite element $(F E)$ codes for predicting structural stiffness and strength of the structures under quasistatic loading with relevant materials data. The aim of the present work is to optimize the Fuel tank Access Cover. As the weight optimization of each component in the Aircraft plays as a significant role in the performance of the aircraft. The $3 D$ modeling of fuel tank access plate is designing using PRO-E and FEA analysis especially structural analysis was done using ANSYS. The structural strength of the Inner Cover, Outer Cover, and Fasteners are validated.
\end{abstract}

\section{Objectives}

- To study about the FTAC design.

- To study various conditions which can be replicated to get the most approximate results?

- To demonstrate a CAD model of FTAC by using predominant software PRO (E).

- To develop a Finite Element Model of Fuel Tank Access Cover accurately to the dimensions with the limited information available as any company does not release all the designs data.

To determine the structural behavior of Fuel Tank Access Cover with different boundary conditions by using ANSYS software.

\section{INTRODUCTION}

Fuel tank access cover (outer FTAC) of an aircraft adapted for being used to cover the outer opening of a void area of a manhole for accessing the interior of a wing of an aircraft wherein the interior of the wing comprises a fuel tank comprises an explosion gases relief adapted for letting the explosion gases from the void area to the atmosphere. Outer FTAC according to claim wherein the relief comprises a frangible line located on the cover and calibrated for being ruptured once a predetermined level of pressure due to explosion gases reached.FTAC according to claim wherein the relief comprises of frangible region, preferably a disk, adapted to be opened once a predetermined level of pressure is reached.

Fuel tank access cover (FTAC) of an aircraft adapted for comprising clipping means for fixing the door to the FTAC wherein such door is adapted to pop-off and the clipping means are adapted to be broken or deflected once a predetermined level of pressure due to explosion gasses is reached. Wherein the the number of orifices are located in such a way that the orifices follow a direction according to the streamlines of the air flow when the aircraft is flying under cruise condition. FTAC is elongated showing two ends wherein it comprises two pluralities of orifices, which are cluster distributed as aline according to the stream line of the close to each end, providing a two hole pattern, one pattern in each end.

FTAC comprises a inner cover located in the inner side of the outer FTAC brtween which a chamber is enclosed such that : the open vent is in communication with the chamber and the chamber is also in communication with the void area by an opening.Inner cover of the FTAC comprises a pressure baffle such that the chamber is divided at least in two sub-chambers: a first sub-chamber in communication with the void area through the opening and a second subchamber in communication eith the first sub-chamber and also in communication with the open vent.

."Manholes in aircrafts provide access to the fuel tank. Manholes comprise an inner fuel tank access cover (inner FTAC), an outer FTAC and a void area between the two covers". 
2. METHODOLOGY

\begin{tabular}{|c|c|c|}
\hline $\begin{array}{l}\text { PRE- } \\
\text { PROCESSOR } \\
\text { PHASE }\end{array}$ & $\begin{array}{l}\text { SOLUTION } \\
\text { PHASE }\end{array}$ & $\begin{array}{l}\text { POST } \\
\text { PROCESSOR } \\
\text { PHASE }\end{array}$ \\
\hline $\begin{array}{l}\text { Geometry } \\
\text { definitions }\end{array}$ & $\begin{array}{l}\text { Element matrix } \\
\text { formulation }\end{array}$ & $\begin{array}{l}\text { Post solution } \\
\text { operation }\end{array}$ \\
\hline Mesh generation & $\begin{array}{l}\text { Overall matrix } \\
\text { triangulation }\end{array}$ & $\begin{array}{l}\text { Post data print } \\
\text { out }\end{array}$ \\
\hline $\begin{array}{l}\text { Materials } \\
\text { definition }\end{array}$ & Wave front & Post data display \\
\hline $\begin{array}{l}\text { Constraint } \\
\text { definition }\end{array}$ & $\begin{array}{l}\text { Displacement, } \\
\text { stress, etc. }\end{array}$ & \\
\hline Load definition & Calculations & \\
\hline
\end{tabular}

\section{GEOMETRICAL DESIGN FTAC}

\section{Component1}

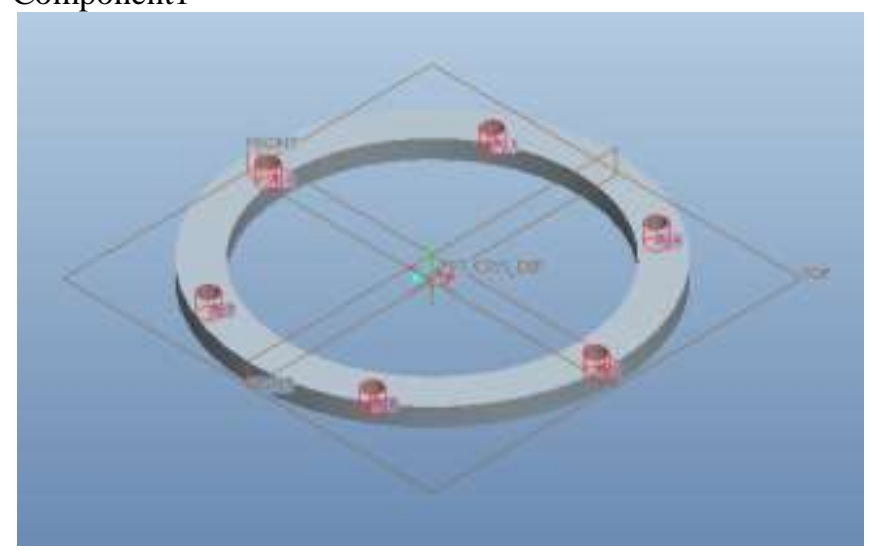

Fig. 1 design of comp1

\section{Component2}

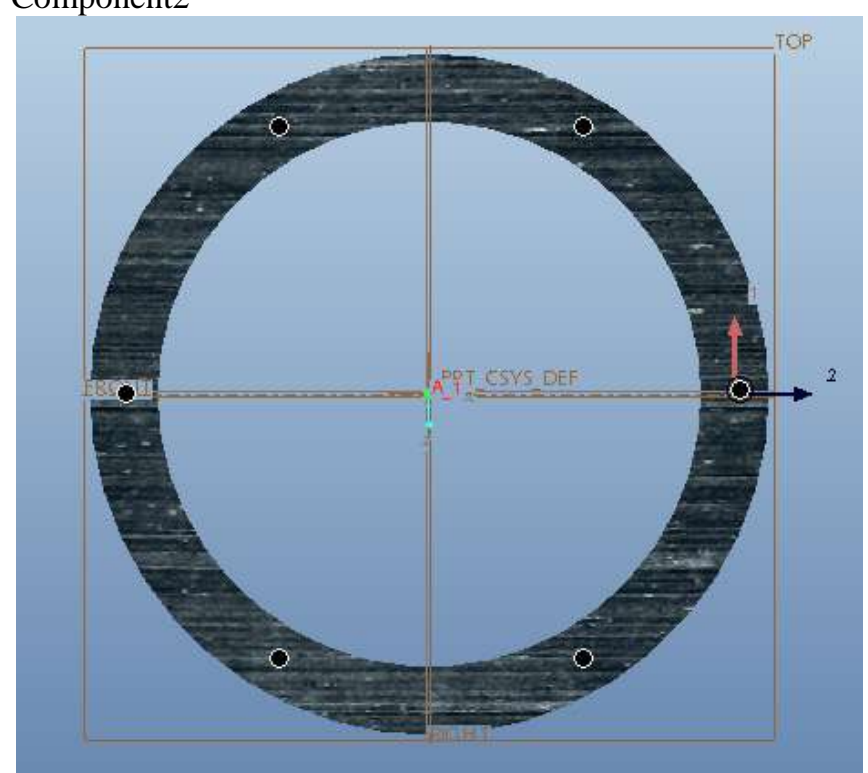

Fig. 2 design of comp2

\section{Component 3}
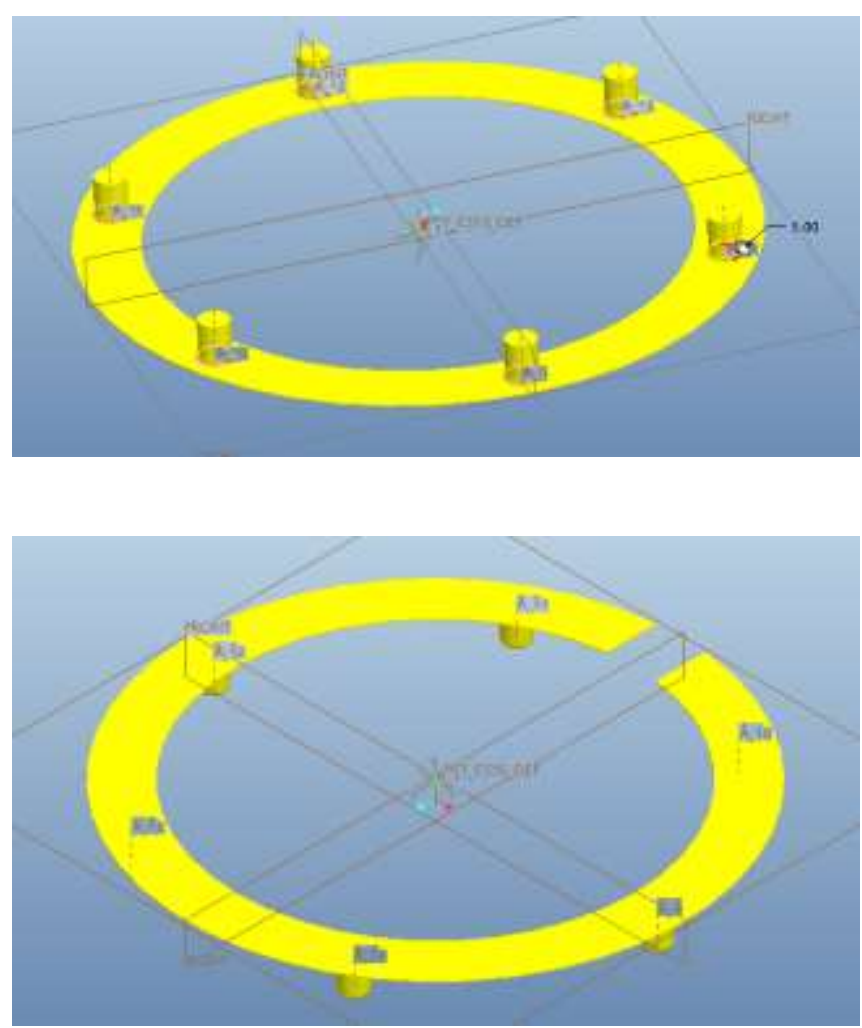

Fig. 3 design of comp3

\section{Component 4}
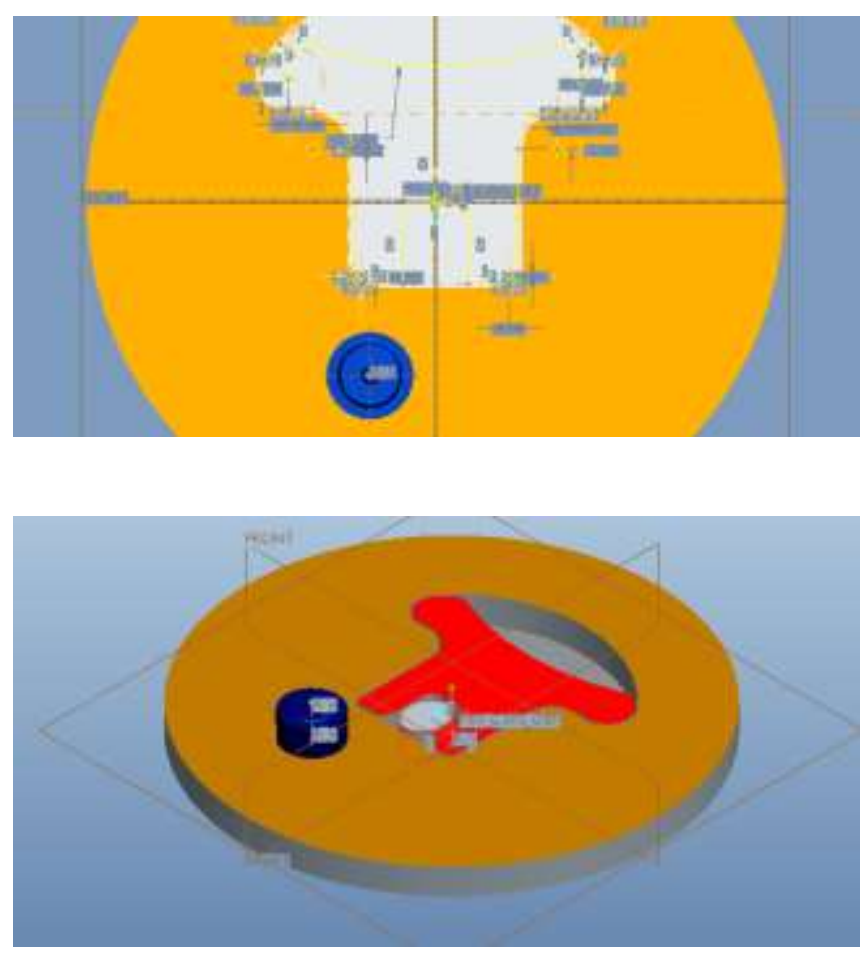

Fig. 4 design of comp 4. 
Table 2 Design dimensions

\begin{tabular}{|l|l|l|l|l|l|l|l|}
\hline $\begin{array}{l}\text { S1 } \\
\text { no. }\end{array}$ & Components & $\begin{array}{l}\text { Outer } \\
\text { diameter }(\mathrm{mm})\end{array}$ & $\begin{array}{l}\text { Inner } \\
\text { diameter }(\mathrm{mm})\end{array}$ & $\begin{array}{l}\text { Depth of } \\
\text { plate }(\mathrm{mm})\end{array}$ & $\begin{array}{l}\text { Holes } \\
\text { diameter(mm) }\end{array}$ & $\begin{array}{l}\text { Extrusion } \\
\text { depth(mm) }\end{array}$ & $\begin{array}{l}\text { Round } \\
(\mathrm{mm})\end{array}$ \\
\hline 1 & 1 & 1000 & 800 & 50 & 50 & - & - \\
\hline 2 & 2 & 1000 & 800 & 25 & 50 & - & - \\
\hline 3 & 3 & 1000 & 800 & 25 & - & 20 & 5 \\
\hline 4 & 4 & 800 & 700 & - & - & - & - \\
\hline
\end{tabular}

\section{ASSEMBLY:}
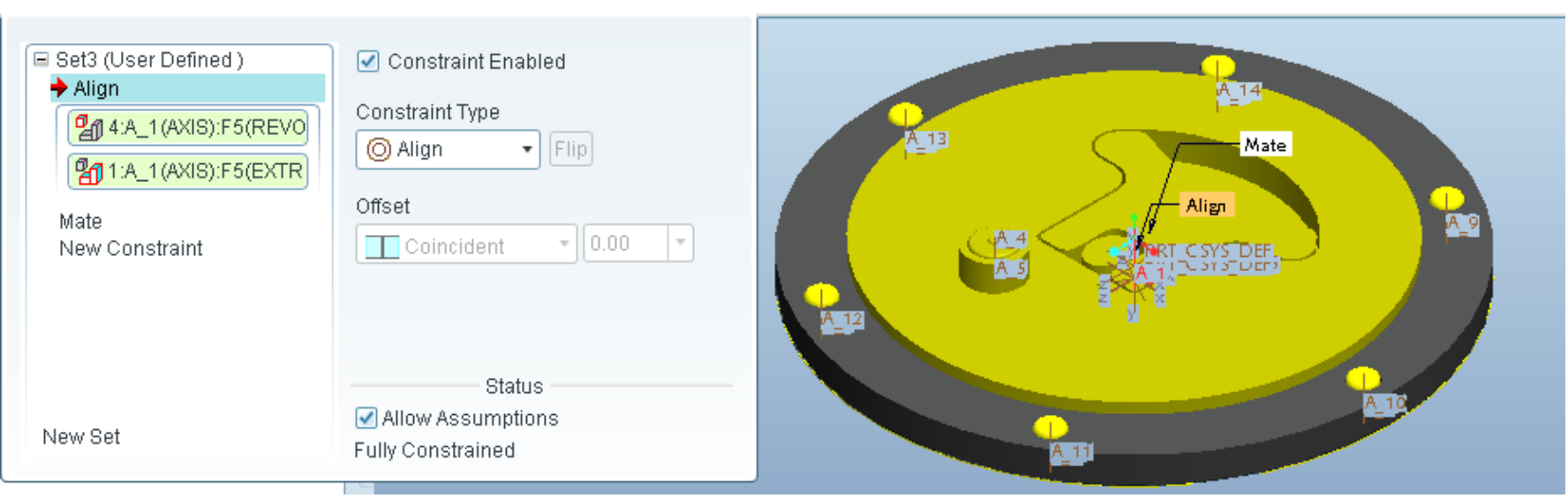

Fig. 5 Assembly of all components.

\section{MATERIAL SPECIFICATION}

Selection of aircraft materials depends on any considerations, which can in general be categorized as cost and structural performance

\section{ALUMINUM ALLOY 2024-T3 STRUCTURAL STEEL}

Table 3 : Material properties used for the analysis.

\begin{tabular}{|l|l|l|}
\hline \multicolumn{1}{|c|}{ Property } & $\begin{array}{l}\text { Aluminum } \\
\mathbf{2 0 2 4 - T 3}\end{array}$ & $\begin{array}{l}\text { Structural } \\
\text { steel }\end{array}$ \\
\hline Density & $2.77 \mathrm{~g} / \mathrm{cm} 3$ & $7,800 \mathrm{~kg} / \mathrm{m}^{3}$ \\
\hline Ultimate Tensile Strength & $483 \mathrm{MPa}$ & $450 \mathrm{MPa}$ \\
\hline Tensile Yield Strength & $362 \mathrm{MPa}$ & $345 \mathrm{MPa}$ \\
\hline Young's Modulus & $72 \mathrm{GPa}$ & $200 \mathrm{Gpa}$ \\
\hline Poisson's Ratio & 0.33 & 0.33 \\
\hline FractureToughness & $72.37 \mathrm{MPa} \sqrt{\mathrm{m}}$ & $54 \mathrm{MPa} \sqrt{\mathrm{m}}$ \\
\hline
\end{tabular}

\section{STRUCTURAL ANALYSISALUMINUM ALLOY 2024-T3}

\section{At Load 2000N}

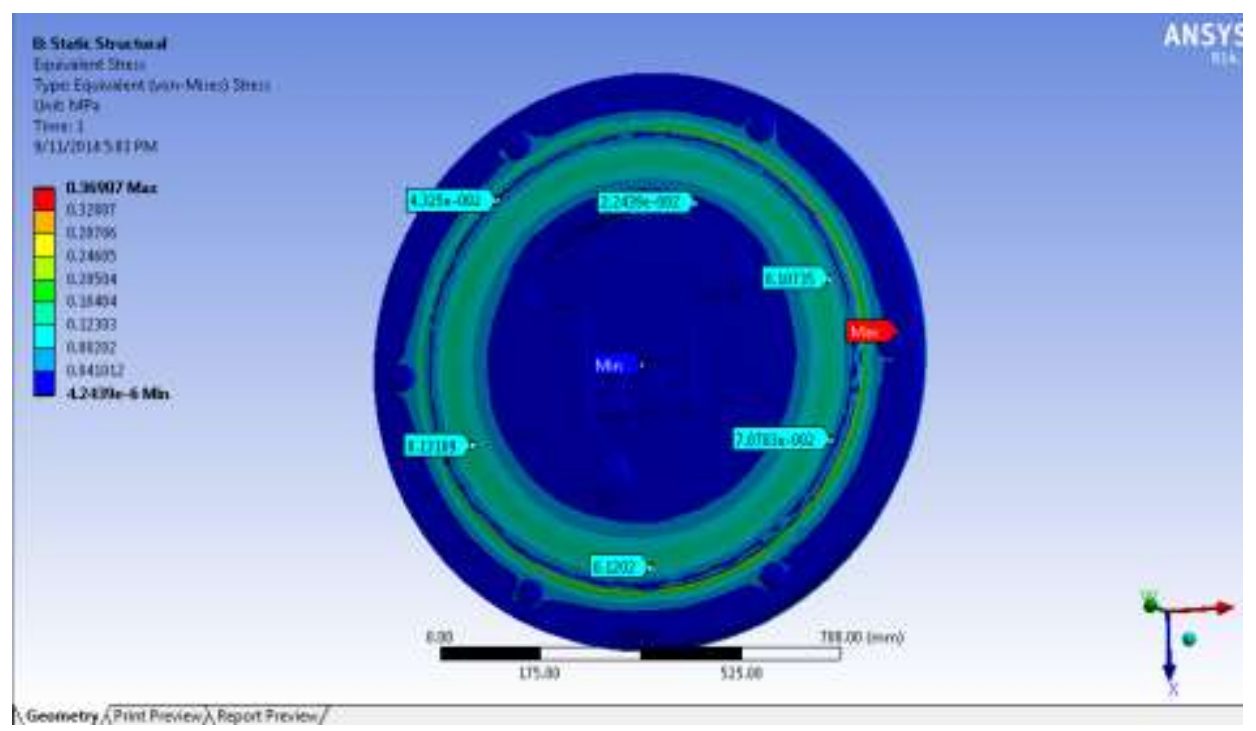




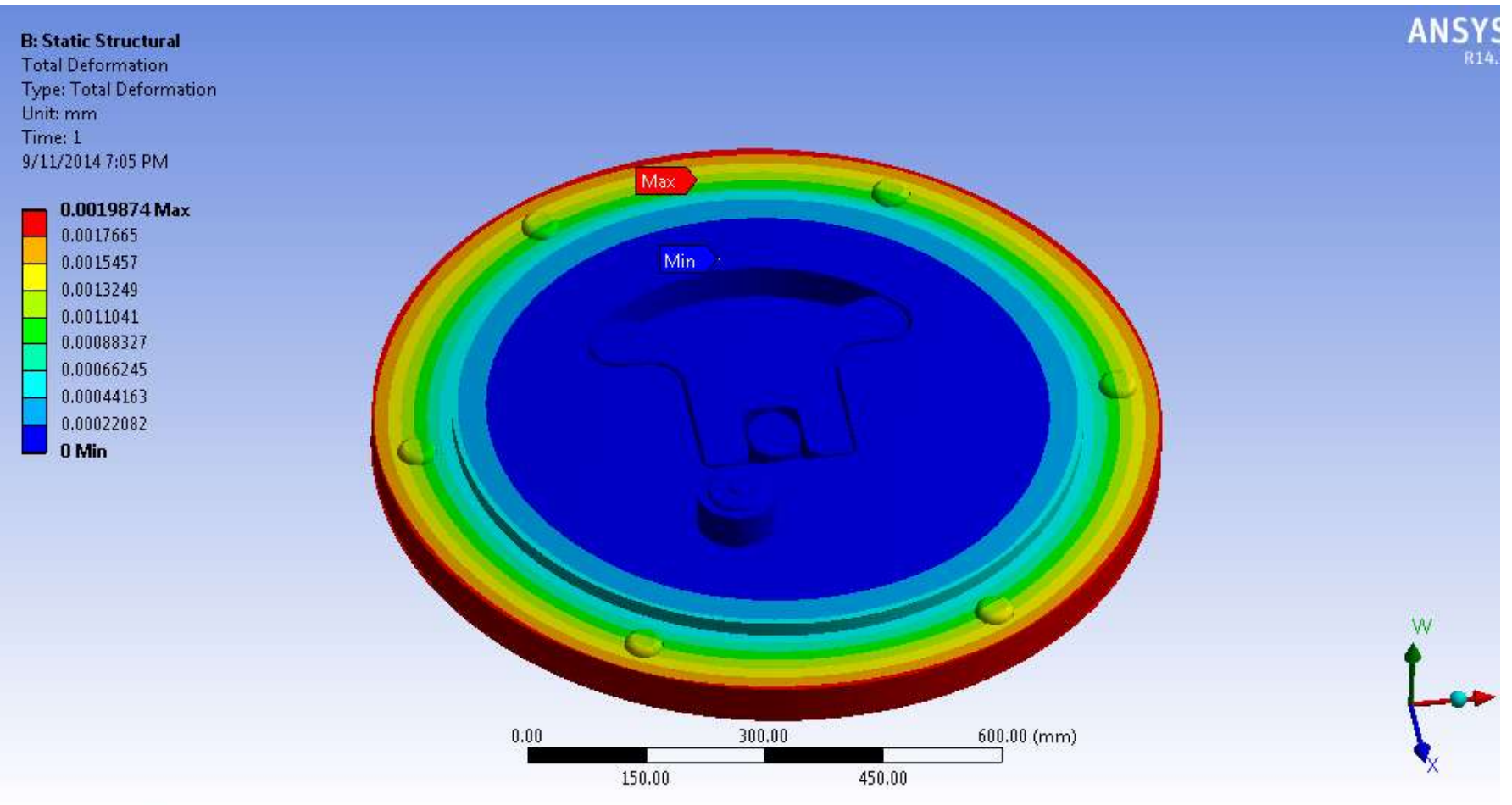

$\bigwedge$ Geometry $/$ Print Preview $\lambda$ Report Preview/

Fig.6 Total deformation (mm) \& equivalent stress (mpa) at 2000n load.

\section{At Load 4000 N}

B: Static Structural

Equivalent Stress

Type: Equivalent (von-Mises) Stress

Unit: $\mathrm{MPa}$

Time: 1

9/11/2014 8:09 PM
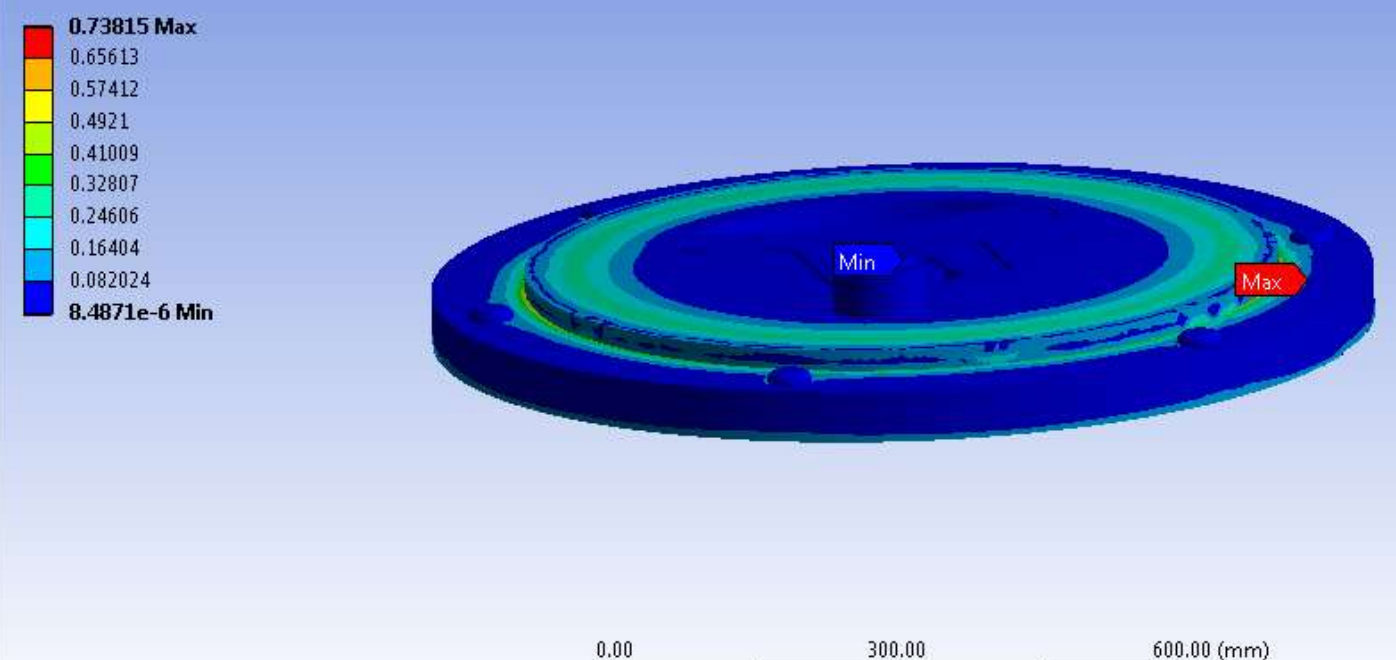

300,00

$600.00(\mathrm{~mm})$

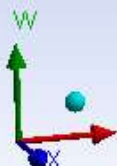

$\$ Geometry $/$ Print Preview $\lambda$ Report Preview/ 


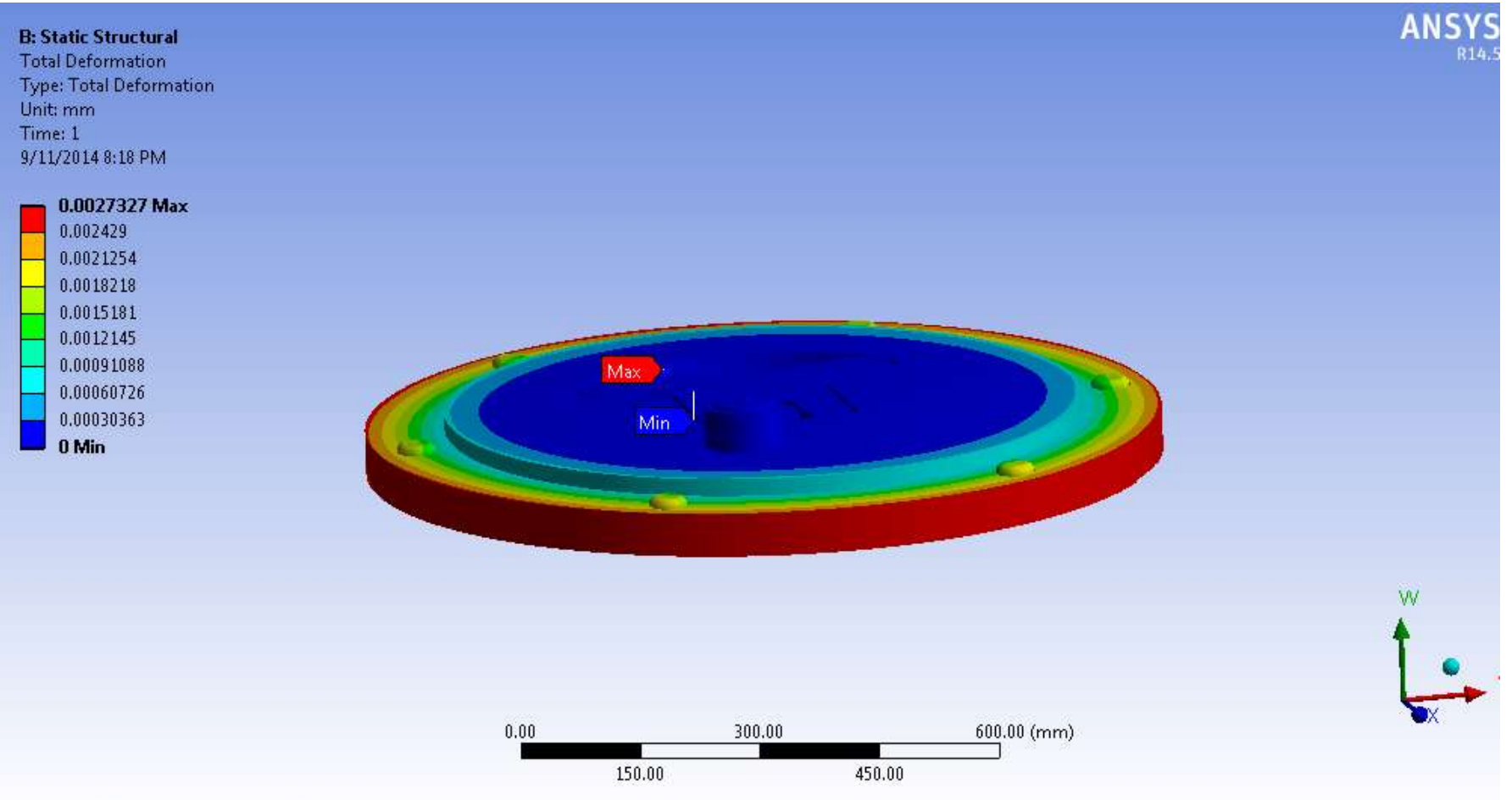

$\backslash$ Geometry $/$ Print Preview $\lambda$ Report Preview/

Fig.7 Total deformation (mm) \& equivalent stress (mpa) at 4000n load.

\section{STRUCTURAL STEEL}

\section{At Load 2000}

\section{B: Static Structural}

Equivalent Stress

Type: Equivalent (von-Mises) Stress

Unit: MPa

Time: 1

9/11/2014 5:56 PM

\begin{tabular}{|l}
$\mathbf{0 . 3 8 4 1 8}$ Max \\
0.34149 \\
0.29881 \\
0.25612 \\
0.21343 \\
0.17075 \\
0.12806 \\
0.085376 \\
0.04269 \\
$\mathbf{4 . 6 1 3 7 e - 6}$ Min
\end{tabular}
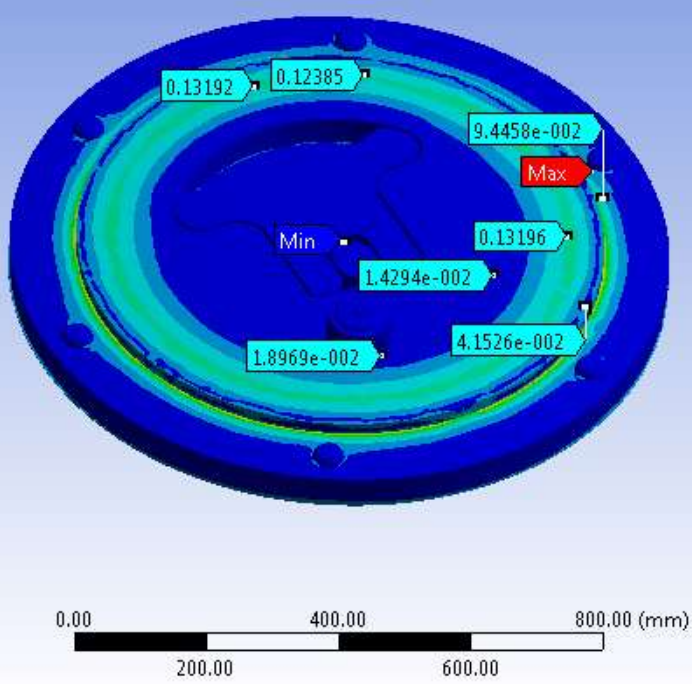

400.00 $800.00(\mathrm{~mm})$

200.00

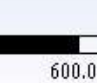

$\Delta$ Geometry $/$ Print Preview $\lambda$ Report Preview/ 


\section{At Load 4000}

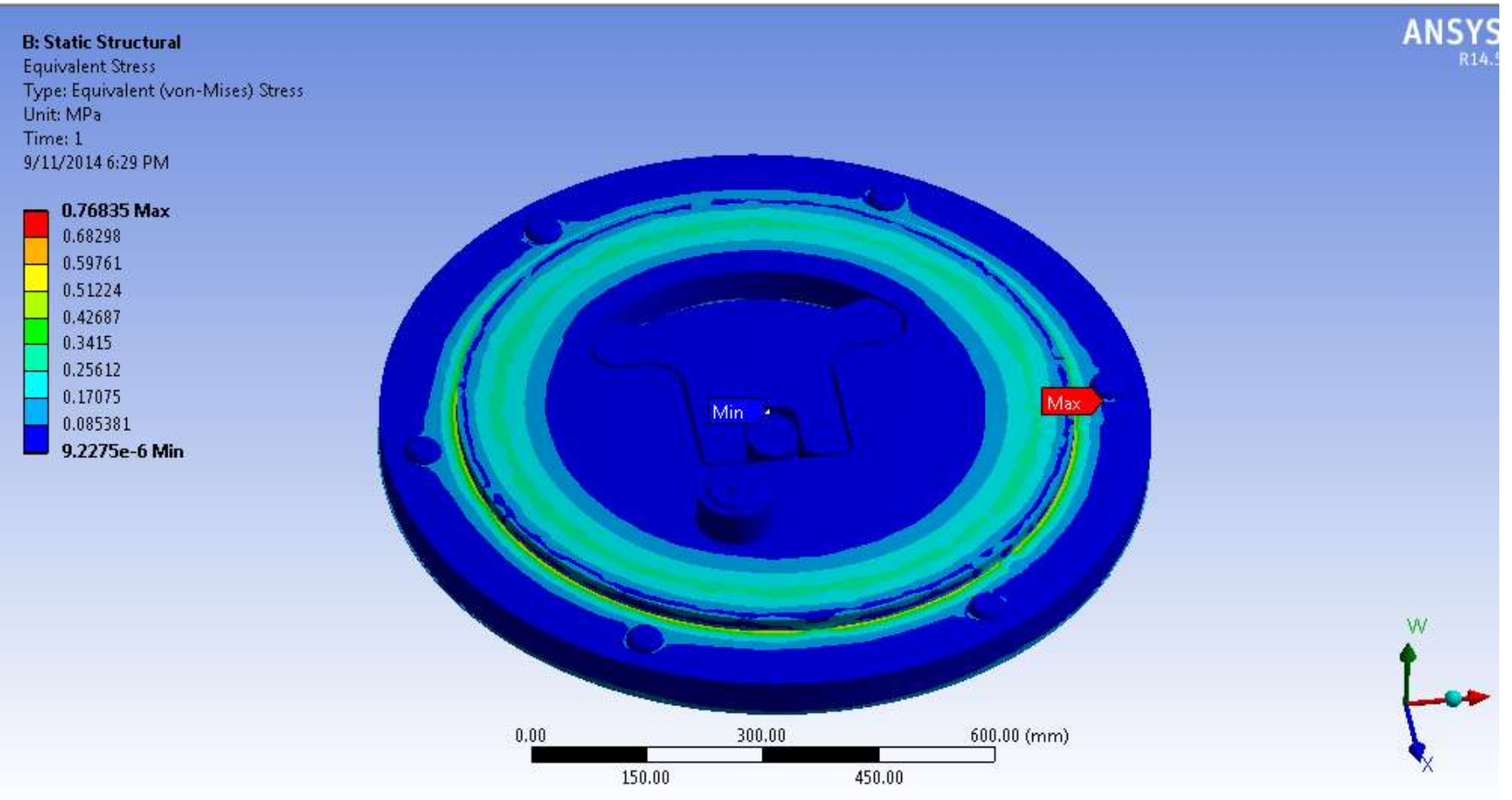

$\bigwedge$ Geometry/Print Preview $\lambda$ Report Preview/
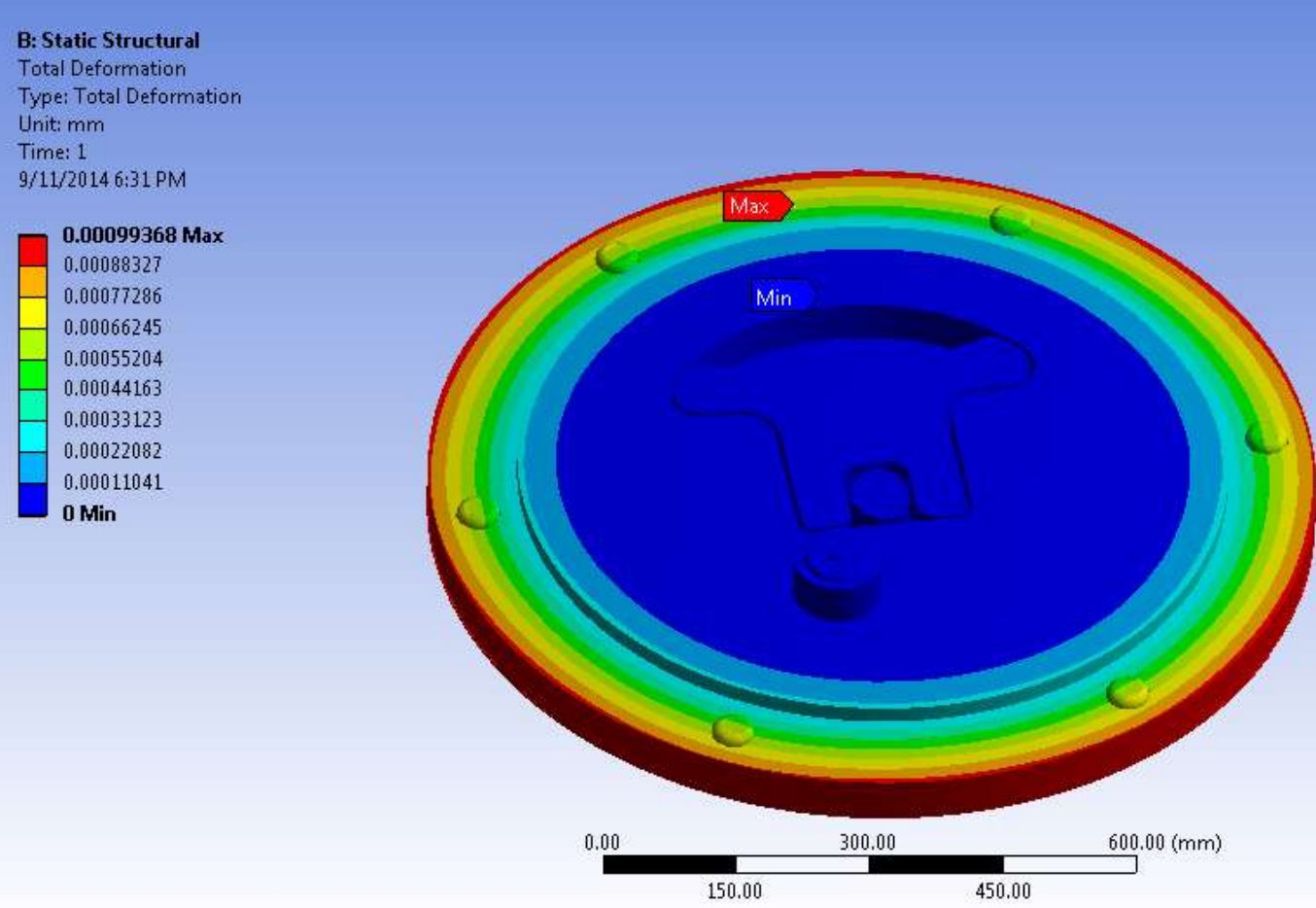

Total Deformation

Unit: $\mathrm{mm}$

9/11/2014 6:31PM

\begin{tabular}{|l|l}
$\mathbf{0 . 0 0 0 9 9 3 6 8}$ Max \\
0.00088327 \\
0.00077286 \\
0.00066245 \\
0.00055204 \\
0.00044163 \\
0.00033123 \\
0.00022082 \\
0.00011041 \\
0 Min
\end{tabular}

Fig 8 equivalent stress and total deformation at 4000 


\section{RESULTS AND DISCUSSIONS}

\section{AL ALLOY 2024-T3}

Table 4: equivalent stress and total deformation at different load condition.

\begin{tabular}{|l|l|l|l|}
\hline S.NO & $\begin{array}{l}\text { LOAD } \\
(\mathrm{n})\end{array}$ & $\begin{array}{l}\text { EQUIVALENT } \\
\text { STRESS }(\mathrm{mpa})\end{array}$ & $\begin{array}{l}\text { TOTAL } \\
\text { DEFORMATION } \\
(\mathrm{mm})\end{array}$ \\
\hline 1 & 2000 & 0.3607 & 0.0019874 \\
\hline 2 & 4000 & 0.73815 & 0.0027327 \\
\hline
\end{tabular}

\section{STRUCTURAL STEEL}

Table 5: Structural steel

\begin{tabular}{|l|l|l|l|}
\hline S.NO & LOAD & $\begin{array}{l}\text { EQUIVALENT } \\
\text { STRESS }\end{array}$ & $\begin{array}{l}\text { TOTAL } \\
\text { DEFORMATION }\end{array}$ \\
\hline 1 & 2000 & 0.38148 & 0.0064532 \\
\hline 2 & 4000 & 0.76835 & 0.00099368 \\
\hline
\end{tabular}

\section{CONCLUSION AND FUTURE SCOPE}

The objective of our project is to design and analysis of fuel tank access plate was completed by using advanced modeling software pro-e and ansys. Stress analysis of a fuel tank access cover is carried out, the max tensile stress identified at the bottom of the skin (@rivet hole). Modal analysis done for natural frequency with aluminium alloy 2024-T3, structural steel and total deformation was completed and structural analysis was done at different load condition from $2000 \mathrm{~N}$ to $4000 \mathrm{~N}$, verified the respective conditions of access plate.

Future scope - I have considered the peak load conditions for analysis over fuel tank access cover, by that stresses achieved and by the material property of alloy, we can suggest the best material alloy for the manufacturing.

\section{REFERENCES}

[1]. http://www.seabuilt.com/demo.php

[2]. http://www.ebay.com/item/Aircraft-shaw-Aero-416-50fuel-tank-gas-cap-piper-Beech-cessna-

/251641932521?pt=Motors_Aviationpartsgear\&hash=item3 a97072ae9

[3]. Richard A Everett Jr., "The effects of load sequencing on the fatigue life of 2024-T3 Aluminium alloy". International Journal of Fatigue.

[4]. Aircraft structures by T H G Megsan.

[5]. Structure And Properties Of Engineering Materials by V. S. R. Murthy.

[6]. Introduction ToAnsys 10.0by R.B. Choudary.

[7]. E. F. Bruhn, Analysis and Design of Flight Vehicle Structures, Jacobs Publishing Company, Arizona, USA.

[8]. Aircraft Design: a conceptual approach by Daniel P. Raymer, President, conceptual research corporation, Sylmar, California. 